\title{
DOI: 10.22620 /agrisci.2021.31.005 \\ CORRELATION AND PATH COEFFICIENT ANALYSES OF GRAIN YIELD AND ITS RELATED COMPONENTS FOR SOME COMMON WINTER WHEAT GENOTYPES
}

\author{
Gergana N. Desheva*, Manol G. Deshev
}

Institute of Plant Genetic Resources "Konstantin Malkov”, Sadovo, Druzhba Str., 4122, BULGARIA *E-mail: gergana_desheva@abv.bg

\begin{abstract}
The aim of the study was to determine the interrelationship and the direct and indirect effects of some yield components among themselves and with the grain yield in the 49 common winter wheat varieties originating from different countries. The experiment was conducted in the experimental field of IPGR-Sadovo, Bulgaria during 2017-2019 growing seasons in the randomized block design in three replications and $10 \mathrm{~m}^{2}$ plot size. Data were recorded for a number of days to heading, plant height, spike length, number of spikelets per spike, number of grains per spike, grain weight per spike, thousandkernels weight and grain yield per hectar. Grain yield per ha correlated positively and significantly with plant height, spike length, grain weight per spike and thousand grain weight. Path coefficient analysis revealed that the grain weight per spike, spike length and plant height had the highest direct positive effect on the grain yield per hectar. The results of study could be useful as selection criteria to increase the grain yield in common winter bread wheat.
\end{abstract}

Key words: correlation, path analysis, common winter wheat, yield, yield components

\section{INTRODUCTION}

One of the main goals in wheat breeding is to increase the grain yield. The wheat yield is the complex polygenic trait, depending on genetic and environmental factors and their interaction (Shara et al., 2016; Chitralekha et al., 2017). The genetic architecture of the yield can be resolved better by studying its component characters as: plant height, number of productive tillers per plant, number of spikelet per spike, number of grains per spike, grain weight per spike, thousand kernels mass and others (Khan and Dar, 2010). Initiating a breeding program based on the yield component requires knowledge of the relationship between the yield and its component characters. Therefore, the correlation is a realistic technique to develop selection criteria mostly based on phenotypic characters used for the improvement of yield through plant breeding programs (Ghallab et al., 2017; Shahidullah et al., 2017;
Noopur et al., 2019). The importance to asses the correlations present among the different traits to be improved has long been recognized by a number of works. Some of the researchers indicated the positive correlation between the grain yield and the yield components traits in wheat such as: the plant height (Kamani et al., 2017), the number of productive tillers per plant (Bhutto et al., 2016; Kamani et al., 2017; Mecha et al., 2017), the number of spikelets per spike (Mecha et al., 2017; Dagade et al., 2020), the number of spikes per plant (Fellahi et al., 2013), the number of grains per spike (Bhutto et al., 2016; Shahidullah et al., 2017; Chitralekha et al., 2017; Dagade et al., 2020), the number of spikes per $\mathrm{m}^{2}$ (Sokoto et al., 2012; Renu et al., 2018), the biological yield (Kamani et al., 2017; Shahidullah et al., 2017; Verma et al., 2019) and the harvest index (Ali and Shakor, 2012; Kamani et al., 2017; Mecha et al., 2017; Verma et al., 2019). 
Simple correlation analysis indicates the degree of association between the traits, but it can't provide reasons for the association. The better understanding of the association is provided by the path coefficient analysis (Shah et al., 2010; Desheva, 2016). It helps in partitioning of correlation coefficients into direct and indirect effects and in the assessment of the relative contribution of each component character to the yield (Verma et al., 2019). Noopur et al. (2019) noted that the information related to the nature and extent of association among the various yield attributes, the direct and indirect effects of each component on the yield are helpful in formulating an effective breeding strategy.

The aim of the study was to determine the interrelationship and the direct and indirect effects of some yield components among themselves and with the grain yield in the common winter wheat.

\section{MATERIALS AND METHODS}

The present study was carried out in the experimental field of the Institute of Plant Genetic Resources "Konstantin Malkov" Sadovo during 2017-2019 growing seasons which is located at longitude $024^{\circ} 55^{\prime} 56.3^{\prime}$ ' $\mathrm{E}$ and latitude $47^{\circ} 07^{\prime} 42.6^{\prime}$ ' $\mathrm{N}$ with an average altitude of $166 \mathrm{~m}$ above sea level in the south of Bulgaria. Forty eigth common winter wheat varieties from different countries (Bulgaria, the Czech Republic, Portugal, France, Poland, Italy, Spain, and Greece) and one accession with unknown biological status and origin were examined (Table 1). The experiment was conducted in the randomized block design with three replications and $10 \mathrm{~m}^{2}$ plot size. Normal agronomic and cultural practices were applied to the experiment throughout the growing seasons. In the phase of full maturity of the plants, 20 plants were selected from each accession for biometric measurements. Data were recorded for plant height, spike length, number of spikelets per spike, number of grains per spike, grain weight per spike, thousandkernels weight and grain yield per hectar. Number of days to heading is calculated from 1 January to the full heading.

Statistical analyses were performed using the statistical program SPSS 19.0. Phenotypic correlations among the various characters were calculated by using phenotypic variances and covariance (Lidansky, 1988). The path coefficient analysis was performed to assess the direct and indirect effects of the measured traits on the grain yield according to Dewey \& Lu (1959).

Table 1. List of accessions included to the study

\begin{tabular}{|c|l|l|l|l|c|}
\hline № & $\begin{array}{l}\text { Accession } \\
\text { number }\end{array}$ & Plant species & Subspecies & $\begin{array}{l}\text { Name of } \\
\text { cultivar }\end{array}$ & Origin \\
\hline 1 & A1BM0256 & Triticum aestivum L. & var. erythrospermum (Koern.) Mansf. & Enola & BGR \\
\hline 2 & B2000213 & Triticum aestivum L. & var.lutescens (Alef.) Mansf. & Ines & CZE \\
\hline 3 & B2000217 & Triticum aestivum L. & var.lutescens (Alef.) Mansf. & Bohemia & CZE \\
\hline 4 & B2000218 & Triticum aestivum L. & var.lutescens (Alef.) Mansf. & Baletka & CZE \\
\hline 5 & B2000226 & Triticum aestivum L. & var.lutescens (Alef.) Mansf. & Secese & CZE \\
\hline 6 & B2000227 & Triticum aestivum L. & var.lutescens (Alef.) Mansf. & Seladon & CZE \\
\hline 7 & B2000228 & Triticum aestivum L. & var.lutescens (Alef.) Mansf. & Silueta & CZE \\
\hline 8 & B2000229 & Triticum aestivum L. & var. erythrospermum (Koern.) Mansf. & Coa & PRT \\
\hline 9 & B2000230 & Triticum aestivum L. & var. erythrospermum (Koern.) Mansf. & Jordao & PRT \\
\hline 10 & B2000234 & Triticum aestivum L. & var.lutescens (Alef.) Mansf. & Andalou & FRA \\
\hline 11 & B2000236 & Triticum aestivum L. & var.lutescens (Alef.) Mansf. & Muza & POL \\
\hline
\end{tabular}




\begin{tabular}{|c|c|c|c|c|c|}
\hline 12 & B2000239 & Triticum aestivum L. & var.lutescens (Alef.) Mansf. & Kobra Plus & POL \\
\hline 13 & B2000241 & Triticum aestivum $\mathrm{L}$. & var. erythrospermum (Koern.) Mansf. & Alcione & ITA \\
\hline 14 & B2000242 & Triticum aestivum L. & var. erythrospermum (Koern.) Mansf. & Bilancia & ITA \\
\hline 15 & B2000243 & Triticum aestivum L. & var. erythrospermum (Koern.) Mansf. & Carisma & ITA \\
\hline 16 & B2000244 & Triticum aestivum L. & var.lutescens (Alef.) Mansf. & $\begin{array}{l}\text { Delfino } \\
\text { (P 204 A) }\end{array}$ & ITA \\
\hline 17 & B2000245 & Triticum aestivum L. & var. erythrospermum (Koern.) Mansf. & Esperia & ITA \\
\hline 18 & B2000246 & Triticum aestivum $\mathrm{L}$. & var.lutescens (Alef.) Mansf. & Gemini & ITA \\
\hline 19 & B2000247 & Triticum aestivum $\mathrm{L}$. & var.milturum (Alef.) Mansf. & Primoasi & ITA \\
\hline 20 & B2000248 & Triticum aestivum L. & var. erythrospermum (Koern.) Mansf. & Accor & FRA \\
\hline 21 & B2000182 & Triticum aestivum $\mathrm{L}$. & var.lutescens (Alef.) Mansf. & Navarro 150 & ESP \\
\hline 22 & B2000189 & Triticum aestivum $\mathrm{L}$. & var.ferrugineum (Alef.) Mansf. & Albimonte & ESP \\
\hline 23 & B2000209 & Triticum aestivum L. & var. erythrospermum (Koern.) Mansf. & Amarok & FRA \\
\hline 24 & B9BM0070 & Triticum aestivum $\mathrm{L}$. & var.lutescens (Alef.) Mansf. & Geya-1-2010 & BGR \\
\hline 25 & B2BM0106 & Triticum aestivum $\mathrm{L}$. & var.lutescens (Alef.) Mansf. & Geya-1 & BGR \\
\hline 26 & B2000249 & Triticum aestivum L. & var.lutescens (Alef.) Mansf. & Allister & FRA \\
\hline 27 & B2000252 & Triticum aestivum $\mathrm{L}$. & var. erythrospermum (Koern.) Mansf. & Autan & FRA \\
\hline 28 & B2000253 & Triticum aestivum L. & var. erythrospermum (Koern.) Mansf. & Colfiorito & ITA \\
\hline 29 & B2000254 & Triticum aestivum L. & var. erythrospermum (Koern.) Mansf. & Collerosso & ITA \\
\hline 30 & B2000255 & Triticum aestivum $\mathrm{L}$. & var. erythrospermum (Koern.) Mansf. & Vittorio & ITA \\
\hline 31 & B2000257 & Triticum aestivum $\mathrm{L}$. & var.lutescens (Alef.) Mansf. & Bardotka & $\mathrm{CZE}$ \\
\hline 32 & B2000258 & Triticum aestivum L. & var.lutescens (Alef.) Mansf. & Bazilika & $\mathrm{CZE}$ \\
\hline 33 & B2000260 & Triticum aestivum $\mathrm{L}$. & var.lutescens (Alef.) Mansf. & Nikol & $\mathrm{CZE}$ \\
\hline 34 & B2000261 & Triticum aestivum L. & var.lutescens (Alef.) Mansf. & Bodycek & CZE \\
\hline 35 & B2000262 & Triticum aestivum L. & var.lutescens (Alef.) Mansf. & Elly & CZE \\
\hline 36 & B2000263 & Triticum aestivum $\mathrm{L}$. & var. erythrospermum (Koern.) Mansf. & Jindra & $\mathrm{CZE}$ \\
\hline 37 & B2000265 & Triticum aestivum L. & var.lutescens (Alef.) Mansf. & Matylda & CZE \\
\hline 38 & B2000266 & Triticum aestivum L. & var.lutescens (Alef.) Mansf. & Canadair & FRA \\
\hline 39 & B2000268 & Triticum aestivum $\mathrm{L}$. & var.ferrugineum (Alef.) Mansf. & Oropos & GRC \\
\hline 40 & B2000269 & Triticum aestivum L. & var.aureum (Link) Mansf. & Nestor & GRC \\
\hline 41 & B2000275 & Triticum aestivum L. & var.lutescens (Alef.) Mansf. & Altigo & FRA \\
\hline 42 & B2000276 & Triticum aestivum L. & var.lutescens (Alef.) Mansf. & Aldric & FRA \\
\hline 43 & B2000274 & Triticum aestivum L. & var.lutescens (Alef.) Mansf. & Acienda & FRA \\
\hline 44 & B2000169 & Triticum aestivum L. & var. erythrospermum (Koern.) Mansf. & Saturnus & AUT \\
\hline 45 & B2000171 & Triticum aestivum $\mathrm{L}$. & var.lutescens (Alef.) Mansf. & Mahissa-1 & ESP \\
\hline 46 & B2000176 & Triticum aestivum L. & var.lutescens (Alef.) Mansf. & Dimas & ESP \\
\hline 47 & B2000177 & Triticum aestivum L. & var.lutescens (Alef.) Mansf. & Estrella & ESP \\
\hline 48 & B3000080 & Triticum aestivum L. & var.lutescens (Alef.) Mansf. & & unknown \\
\hline 49 & A1BM0322 & Triticum aestivum L. & var.lutescens (Alef.) Mansf. & Sadovo 772 & BGR \\
\hline
\end{tabular}




\section{RESULTS AND DISCUSSION}

\section{Phenotypic correlation}

The phenotypic correlation reveals the degree of association between different characters and thus aids in the selection to improve the yield and the yield attributing characters simultaneously (Ghallab et al., 2017; Verma et al., 2019). The positive correlation between desirable traits is supposed to be favourable and help to breeder in selection whereas, the negative correlations hinder the recovery of the combinations in both characters (Chitralekha et al., 2017). The phenotypic correlation coefficients of the grain yield and its related components in the investigated 49 common winter wheat genotypes are presented in Table 2. The grain yield had a positive and significant correlation with the plant height $\left(\mathrm{r}=0.1821^{*}\right)$, spike length $\left(\mathrm{r}=0.301^{* *}\right)$, grain weight per spike $\left(\mathrm{r}=0.204^{*}\right)$ and thousandkernels weight $\left(\mathrm{r}=0.180^{*}\right)$. The selection for these characters could be directly followed by an immediate yield improvement of the wheat crop (Nukasani et al., 2013). Generally, in those characters in which the grain yield showed a positive and significant correlation, there were component interactions in which a gene conditioning an increase in one character will also influence another character provided the other conditions are kept constant (Mecha et al., 2017). Sokoto et al. (2012), Nasri et al. (2014) and Ojha et al. (2018) also confirm that the plant height, spike length and 1000-grains weight have an importance in yield determination. Mecha et al. (2017), noted that the grain yield had a positive correlation with the spike length and the thousand-kernels weight, while according to Shara et al. (2016), the 1000 kernel weight was in a negative relationship with the grain yield. The positive correlation of the plant height with the grain yield was recorded by Nasri et al. (2014), while the negative by Joshi et al. (2008) and Chitralekha et al. (2017). Tsenov et al. (2009), Rachovska and Uhr (2010), Chamurliyski et al. (2011) and Nukasani et al. (2013) confirmed the positive relationship between the yield and the grain weight per spike, while Mohsin et al. (2009) between the yield and the spike length. Al-Najjar and AlZubaidy (2020) observed a significant and positive correlation between the yield, the plant height and the thousand-kernels weight. Chamurliysky et al. (2014) found a positive relationship between the grain yield, the grain weight per spike and the thousand-kernels weight.

The plant height correlated positively and significantly with the number of days to heading $(\mathrm{r}=0.152 *)$, which was also observed by Yadav et al. (2019) (Table 2). The spike length was in a positive relationship with the number of days to heading $(\mathrm{r}=0.141 *)$ and the plant height $\left(\mathrm{r}=0.221^{* *}\right)$. The last correlation was in agreement with our previous study (Desheva, 2016) and the reports of Sokoto et al. (2012), Ghallab et al. (2017), Chitralekha et al. (2017), Stojsin et al. (2018), Yadav et al. (2019) and Kumari et al. (2020).

The positive correlations appeared between the number of spiklets per spike, the number of days to heading and the spike length, respectively $\left(\mathrm{r}=0.147^{*}\right.$ and $\left.\mathrm{r}=0.233^{* *}\right)$ (Table $2)$. The correlation between the number of spiklets per spike and the spike length was in line with the findings made by NikolovaAndreeva (2011), Bhutto et al. (2016), Mecha et al. (2017), Stojsin et al. (2018) and Dimitrov et al. (2019).

The number of grains per spike correlated positively and significantly with the spike length $\left(\mathrm{r}=0.293^{* *}\right)$ and the number of spiklets per spike $\left(\mathrm{r}=0.291^{* *}\right)$ (Table 2$)$. Our findings were in conformity with Sokoto et al. (2012) and Desheva et al. (2016). Meena et al. (2014), Dutamo et al. (2015), Ojha (2018) and Dimitrov et al. (2019) also noted a positive correlation between the number of grains per spike and the number of spiklets per spike. Stoyanov (2013), Shrief et al. (2019), Haydar et al. (2020) and Bonchev (2020) observed a positive linear relationship of the number of 
grains per spike with the spike length.

The grain weight per spike correlated positively with the spike length $(\mathrm{r}=0.432 * *)$, the number of spiklets per spike $\left(r=0.306^{* *}\right)$ and the number of grains per spike $(\mathrm{r}=0.717 * *)$ (Table 2). The results were coincident with those reported by Stojsin et al. (2018). Kamani et al. (2017) and Dimitrov et al. (2019) also found a positive relationship between the grain weight per spike and the number of grains per spike. Meena et al. (2014) in contrast to our study found a negative relationship between the grain weight per spike and the number of spiklets per spike and the number of grains per spike.

The thousand-kernels weight showed a positive correlation with the plant height $\left(\mathrm{r}=0.218^{* *}\right)$, the spike length $\left(\mathrm{r}=0.218^{* *}\right)$ and the grain weight per spike $\left(\mathrm{r}=0.471^{* *}\right)$, while it was negative with the number of grains per spike $(\mathrm{r}=-0.250 * *)$ (Table 2$)$. The negative relationship found in this study was in agreement with previous reports of Fellahi et al. (2013), Shara et al. (2016), Mecha et al. (2017), Bonchev (2020) and in contraversaly with Kamani et al. (2017). A positive correlation between the thousand-kernels weight and the grain weight per spike was recorded by Nikolova-Andreeva (2011), Nikolova (2012), Stoyanov (2013), Bhutto et al. (2016) and Stoyanov and Dunchev (2020), while Yadav et al. (2019) observed a negative correlation of the thousand-kernels weight with the spike length. Dragov and Dechev (2016) found a positive relationship between the thousand-kernels weight and the plant height in durum wheat.

Shrief et al. (2019) confirmed a positive relationship between the thousand-kernels weight and the spike length.

Table 2. Phenotypic correlation coefficients of grain yield and its related components in common winter wheat

\begin{tabular}{|l|l|l|l|l|l|l|l|l|}
\hline Variable & NDH & PH & SL & NSS & NGS & GWS & TKW & GY \\
\hline NDH & 1 & & & & & & & \\
\hline PH & $\mathbf{0 . 1 5 2}^{*}$ & 1 & & & & & & \\
\hline SL & $\mathbf{0 . 1 4 1}^{*}$ & $\mathbf{0 . 2 2 1} * *$ & 1 & & & & & \\
\hline NSS & $\mathbf{0 . 1 4 7}^{*}$ & 0.086 & $\mathbf{0 . 2 3 3} * *$ & 1 & & & & \\
\hline NGS & -0.023 & -0.134 & $\mathbf{0 . 2 9 3}^{* *}$ & $\mathbf{0 . 2 9 1} 1^{* *}$ & 1 & & & \\
\hline GWS & 0.056 & 0.046 & $\mathbf{0 . 4 3 2}^{* *}$ & $\mathbf{0 . 3 0 6} * *$ & $\mathbf{0 . 7 1 7} * *$ & 1 & & \\
\hline TKW & 0.117 & $\mathbf{0 . 2 1 8}^{* *}$ & $\mathbf{0 . 2 1 8}^{* *}$ & 0.019 & $\mathbf{- 0 . 2 5 0} * *$ & $\mathbf{0 . 4 7 1}^{* *}$ & 1 & \\
\hline GY & 0.086 & $\mathbf{0 . 1 8 2}^{*}$ & $\mathbf{0 . 3 0 1}^{* *}$ & -0.028 & 0.067 & $\mathbf{0 . 2 0 4}^{* *}$ & $\mathbf{0 . 1 8 0}^{*}$ & 1 \\
\hline
\end{tabular}

*. Correlation is significant at the 0.05 level (2-tailed), **. Correlation is significant at the 0.01 level (2-tailed).

NDH-number of days to heading, PH-plant height, SL-spike length, NSS-number of spiklets per spike, NGS-number of grains per spike, GWS- grain weight per spike, GY-grain yield per hectar, TKWthousand-kernels weight

\section{Path coefficient analysis}

The path coefficients studied the causes and effects and also studied the relationships between the variables which are differentiated the associations into direct and indirect effects through other dependent variables (Kumari et al., 2020). Generally, the characters that exerted a positive direct effect and a positive and significant correlation coefficient with the grain yield were known to affect the grain yield in the favourable direction and need much attention during the process of selection cases (Ojha et al., 2018). The direct and indirect effects of the investigated 7 characters (independent variables) on the grain yield per hectar (dependent variable) are presented in Table 3. 
The grain weight per spike had the greatest positive effect $(0.525)$ on the grain yield per hectar, followed by the spike length (0.242) and the plant height (0.111). Therefore a slight increase in one of these traits may directly contribute to the grain yield per ha. These traits are very important components of the grain yield and should be given a high weightage in any selection process aimed at improving grain yield in common winter wheat. Nukasani et al. (2013), Meena et al. (2014) also exhibited a maximum positive direct effect of the grain weight per spike on the yield. Mohsin et al. (2009) also indicated that the grain yield had a positive direct effect with the spike length and the number of grains per spike. Al-Maliky (2018) found the highest direct effect of the plant height on the grain yield variation. Shara et al. (2016) in contraversary to our study found a negative direct effect of the grain weight per spike on the grain yield, while Ojha et al. (2018) noted a negative direct effect of the plant height. The deviations of our results from those of the above mentioned authors may be due to the different set of samples included in the experiments, on the one hand, and on the other, due to the fact that the yield as a polygenic nature is strongly influenced by fluctuations in the environment.

The highest negative direct effect was observed for the number of grains per spike (0.383). The direct effects of the thousandkernels weight and the number of spiklets per spike on grain yield per ha were also negative, respectively (-0.243 and -0.145$)$ (Table 3). Mecha et al. (2017) in contrast to our study pointed out that the thousand grains weight and the number of grains per spike showed a positive direct effect.

The highest positive total indirect effect showed the number of grains per spike (0.450), followed by the thousand-kernels weight $(0.423)$ and they were controlled via the grain weight per spike (0.376 and 0.247). Only the grain weight per spike had a negative total indirect effect $(-0.321)$ via the number of grains per spike, the thousand-kernels weight, and the spike length, respectively $(-0.275,-0.114$ and 0.104) (Table 3).

Table 3. Direct (Bold and Underline) and indirect effect of the 7 characters (independent variables) on the grain yield per hectar (dependent variable) in 49 common winter wheat genotypes. The last column shows the phenotypic correlations ( $r$ ) of the independent variables with the grain yield per hectar

\begin{tabular}{|c|c|c|c|c|c|c|c|c|c|}
\hline Variable & NDH & PH & SL & NSS & NGS & GWS & TKW & $\begin{array}{c}\text { Total } \\
\text { indirect effect }\end{array}$ & r \\
\hline NDH & $\underline{\mathbf{0 . 0 4 7}}$ & 0.017 & 0.034 & -0.021 & 0.009 & 0.029 & -0.028 & 0.039 & 0.086 \\
\hline PH & 0.007 & $\underline{\mathbf{0 . 1 1 1}}$ & 0.053 & -0.012 & 0.051 & 0.024 & -0.053 & 0.071 & $\mathbf{0 . 1 8 2}$ \\
\hline SL & 0.007 & 0.025 & $\underline{\mathbf{0 . 2 4 2}}$ & -0.034 & -0.112 & 0.227 & -0.053 & 0.059 & $\mathbf{0 . 3 0 1}$ \\
\hline NSS & 0.007 & 0.010 & 0.056 & $\underline{\mathbf{- 0 . 1 4 5}}$ & -0.111 & 0.161 & -0.005 & 0.117 & -0.028 \\
\hline NGS & -0.001 & -0.015 & 0.071 & -0.042 & $\underline{\mathbf{- 0 . 3 8 3}}$ & 0.376 & 0.061 & $\mathbf{0 . 4 5 0}$ & 0.067 \\
\hline GWS & 0.003 & 0.005 & 0.104 & -0.044 & -0.275 & $\underline{\mathbf{0 . 5 2 5}}$ & -0.114 & $\mathbf{- 0 . 3 2 1}$ & $\mathbf{0 . 2 0 4}$ \\
\hline TKW & 0.005 & 0.024 & 0.053 & -0.003 & 0.096 & 0.247 & $\underline{\mathbf{- 0 . 2 4 3}}$ & $\mathbf{0 . 4 2 3}$ & $\mathbf{0 . 1 8 0}$ \\
\hline
\end{tabular}

NDH-Number of days to heading, PH-Plant height, SL-Spike length, NSS-Number of spiklets per spike, NGS-Number of grains per spike, GWS-Grain weight per spike, TKW-thousand-kernels weight

The phenotypic correlation analysis indicated that the thousand-kernels weight and the number of grains per spike had positive influences on the grain yield per ha (Table 2), but the path coefficient analysis suggested that they had a direct negative influence on the grain 
yield per ha (Table 3 ). The results showed that the direct negative effect of the thousandkernels weight and the number of grains per spike on the grain yield per ha were masked from the positive indirect effect of these characters through the grain weight per spike (Desheva, 2016). Terefore, their positive effect on improving the yield was indirect through the increment of grain weight per spike.

Generally, the results of the correlation and path analysis obtained plant heigth, spike length and grain weight per spike, showed a significant positive correlation with the maximum positive direct effect on the grain yield. Therefore, a direct selection on the bases of these traits could be effective for the grain yield improvement of bread wheat for the studied location.

\section{CONCLUSION}

The results obtained from 49 bread wheat genotypes showed that the grain yield per hectar was significantly and positively correlated at a phenotypic level with the plant height, the spike length, the grain weight per spike and the thousand-kernels weight. The path coefficient analysis indicated that the grain weight per spike had the greatest positive effect on the grain yield per hectar, followed by the spike length and the plant height. The number of grains per spike, the thousand-kernels weight and the number of spiklets per spike had a direct negative effect on the yield grain per ha. Therefore, the characters - grain weight per spike, spike length and plant height are the most important characters affecting the grain yield variation and consequently may be considered as effective criteria to increase grain yield in common winter wheat.

\section{REFERENCES}

Ali, I. H., \& Shakor E. F. (2012). Heritability, variability, genetic correlation and path analysis for quantitative traits in durum and bread wheat under dry farming conditions. Mesoptamia Journal of Agriculture, 40(4), 27-39. https://doi.org/10.33899/magrj.2012.59 640.

Al-Maliky, R. J. (2018). Path analysis and correlation coefficient under the effect of different locations for bread wheat. International Journal of Agronomy and Agricultural Research, 13(1), 78-83. https://innspub.net/ijaar/path-analysiscorrelation-coefficient-effect-differentlocations-bread-wheat/.

Al-Najjar, S. M. Y. \& Al-Zubaidy, Kh. M. D. (2020). Correlation and path coefficient analysis in bread wheat. Mesopotamia Journal of Agriculture, 48(1):25-35. https://doi.org/10.33899/magrj.2020.12 6461.1019.

Armin Saed-M, Pessarakli, M. \& Heidari, B. (2013). Comparing relationships among yield and its related traits in mycorrhizal and nonmycorrhizalinoculated wheat cultivars under different water regimes using multivariate statistics. International Journal of Agronomy, 114. https://doi.org/10.1155/2013/682781.

Bonchev, B. (2020). Correlation, direct and indirect effects of common winter wheat (Triticum aestivum L.) cultivar Gaya 1 of potential yield and yield with its elements. Univerity of Agribusiness and Rural Development Yearbook, 7, 271300.

https://science.uard.bg/index.php/yearb ook/article/viewFile/769/703.

El-Mohsen, A. A. A. \& El-Shafi, M. A. A. (2014). Regression and path analysis in Egyptian bread wheat. Journal of AgriFood and Applied Sciences, 2(5), 139148.

http://www.blueap.org/j/List/1/iss/volume\%202\%20(20 14)/issue \%2005/3.pdf. 
Bhutto, A. H., Asghar, A. R., Shahmir, A. K., Amjad, A., Fahad, A. K., Muneer, A., Sajjad, A. \& Niaz, A. K. (2016). Correlation and regression analysis for yield traits in wheat (Triticum aestivum L.) genotypes. Natural Science, 8, 96104. https://doi.org/10.4236/ns.2016.83013.

Chamurliyski, P., Tsenov, N. \& Stoeva, I. (2011). Productivity and quality of modern Bulgarian bread wheat varieties (Triticum aestivum L.). Field Crops Studies, 7(2), 233-241.

http://fcs.dai-

gt.org/bg/index.php?page $=$ tom\&idt $=11$ $\& \mathrm{idb}=20 \& \mathrm{ida}=356$.

Chamurliysky, P., Stoeva, I. \& Penchev, E. (2014). Evaluation of the variation of the traits characterizing the genetic diversity in the common winter wheat (Triticum aestivum L.) working collection. Field Crops Studies, 9(1), 31-40. http://fcs.dai-

gt.org/bg/index.php?page $=$ tom \&idt $=13$ $\& \mathrm{idb}=23 \& \mathrm{ida}=446$.

Chitralekha, S., Chandrakar, P. K., Rastogi, N. K., Banjare, U. \& Densena, M. (2017). Estimation of correlation coefficient study of some quantitative traits in wheat. Annals of Plant Sciences, 7(2), 2078-2081.

https://www.annalsofplantsciences.com /index.php/aps/article/view/434/0.

Dagade, S. K., Dodake, S. S. \& Magar, N. M. (2020). Genetic variability, character association and path coefficient analysis in bread wheat (Triticum aestivum Desf.). Journal of Pharmacognosy and Phytochemistry, 9(6), 2149-2155. https://www.phytojournal.com/archives $/$ ? year $=2020 \&$ vol $=9 \&$ issue $=6 \&$ page $=3$ 2.

Desheva, G. (2016). Correlation and pathcoefficient analysis of quantitative characters in winter bread wheat accessions. Trakia Journal of Sciences, 1 , 24-29. https://doi.org/10.15547/tjs.2016.01.00 3.

Dewey, R. D. \& Lu, K. (1959). A correlation and path coefficient analysis of components of crested wheat grass seed production. Agronomy Journal, 52, 5158.

https://doi.org/10.2134/agronj1959.000 21962005100090002x.

Dimitrov, E., Uhr, Z.P., Velcheva, N. \& Uzunova, K. (2019). Study of elements of productivity and determine the correlation relationships between them in common winter wheat varieties with origin from Belarus. International Journal of Innovative Approaches in Agricultural Research, 3(4), 661-670. https://doi.org/10.29329/ijiaar.2019.217 .12 .

Dragov, R. \& Dechev, D.(2016). Genetic distance by important economic traits between bulgarian and foreign cultivars of durum wheat. Science \& Technologies, 6(6):41-47. http://www.sustz.com/journal/3/1473.p df.

Dutamo, D., Alamerew, S. S., Eticha, F. \& Assefa, E. (2015). Path coefficient and correlation studies of yield and yield associated traits in bread wheat (Triticum aestivum L.) germplasm. World Applied Sciences Journal, 33(11), 1732-1739. https://doi.org/10.5829/idosi.wasj.2015. 33.11.15617.

Fellahi, Z., Hannachi, A., Bouzerzour, H. \& Boutekrabt, A. (2013). Correlation between traits and path analysis coefficient for grain yield and other quantitative traits in bread wheat under Semi Arid conditions. Journal of Agriculture and Sustainability, 3(1), 1626. http://infinitypress.info/index.php/jas/is 
sue/view/16. Ghallab, K. H., AbdelAziz, N. S. \& Samir, K. A. I. (2017). Estimation of genotypic and phenotypic correlations for some growth traits and grain yield of wheat genotypes. International Journal of Agronomy and Agricultural Research, 10(5), 53-58. https://innspub.net/ijaar/estimationgenotypic-phenotypic-correlationsgrowth-traits-grain-yield-wheatgenotypes/.

Haydar, F. M. A., Ahamed, M. S., Siddique, A. B., Uddin, G. M., Biswas, K. L. \& Alam, M. F. (2020). Estimation of genetic variability, heritability and correlation for some quantitative traits in wheat (Triticum aestivum L.). Journal of BioScience, $\quad 28, \quad 81-86$. https://doi.org/10.3329/jbs.v28i0.44713

Hannachi, A., Fellahi, Z. E. A., Bouzerzour, H. \& Boutekrabt, A. (2013). Correlation, path analysis and stepwise regression in durum wheat (Triticum durum Desf.) under rainfed conditions. Journal of Agriculture and Sustainability, 3(2), 122-131.

http://infinitypress.info/index.php/jas/ar ticle/view/108.

Joshi, B. K., Mudwari, A. \& Thapa, D. B. (2008). Correlation and path coefficients among quantitative traits in wheat (Triticum aestivum L.). Nepal Journal of Science and Technology, 9, 1-5. https://doi.org/10.3126/njst.v9i0.3154.

Yadav, M., Kumhar, S. R., Choudhary, R. \& Goyal, G. (2019). Assessment of yield criteria in wheat through correlation and path analysis. Journal of Pharmacognosy and Phytochemistry, 8(2), 1978-1981.

https://www.phytojournal.com/archives/?year= $2019 \&$ vol $=8 \&$ issue $=2 \&$ Article $I d=7965$

Kamani, D. L., Babariya, C. A. \& Marviya, P. B. (2017). Correlation coefficient and path coefficient analysis for yield components in wheat (Triticum aestivum L.). International Journal of Pure and Applied Biosciences, 5(5), 545-552. http://dx.doi.org/10.18782/23207051.2686.

Khan, M. H. \& Dar, A. N. (2010). Correlation and path coefficient analysis of some quantitative traits in wheat. African Crop Science Journal, 18, 9-14, http://dx.doi.org/10.4314/acsj.v18i1.54 188.

Kumari, P., Nitish, D., Kumar, A. \& Kumari, A. (2020). Genetic variability, correlation and path coefficient analysis for yield and quality traits in wheat (Triticum aestivum L.). International Journal of Current Microbiology and Applied Sciences, $\quad 9(1), \quad 826-832$. https://doi.org/10.20546/ijcmas.2020.90 1.089 .

Lidansky, T. (1988). Statistical methods in the biology and in the agriculture. Zemizdat, Sofia.

Mecha, B., Alamerew, S., Assefa, A., Assefa, E. \& Dutamo, D. (2017). Correlation and path coefficient studies of yield and yield associated traits in bread wheat (Triticum aestivum L.) genotypes. Advances in Plants and Agriculture Research, 6(5), 128-136.

https://doi.org/10.15406/apar.2017.06.00226.

Meena, H. S., Kumar, D. \& Prasad, S. R. (2014). Genetic variability and character association in bread wheat (Triticum aestivum). Indian Journal of Agricultural Sciences, 84 (4), 487-91.

Mohsin, T., Khan, N. \& Naqvi, F. N. (2009). Heritability, phenotypic correlation and path coefficient studies for some agronomic characters in synthetic elite lines of wheat. Journal of Food, Agriculture \& Environment, 7(3-4), 278-282.

Nasri, R., Kashani, A., Paknejad, F., Vazan, S. \& Barary, M. (2014). Correlation, path 
analysis and stepwise regression in yield and yield component in wheat (Triticuma estivum L.) under the temperate climate of Ilam province, Iran. Indian Journal of Fundamental and Applied Life Sciences, 4(4), 188-198.

https://www.cibtech.org/J-LIFE-

SCIENCES/PUBLICATIONS/2014/Vo 1-4-No-4/JLS-04-04-Contents.htm.

Nikolova-Andreeva, E. (2011). Relationships between some quantative traits determining productivity of the spike in hybrid combinations winter wheat (Triticum aestivum L.).

http://www.sustz.com/journal/VolumeI/Numbe r6/Papers/ElenaNikolova-Andreeva.pdf.

Nikolova, E. (2012). Heterosis, deppresion, dominant and transgression of the symptom length of spike in winter common wheat hybrids. Science \& Technologies, 2(6):67-72.

Noopur, K., Jawaharlal, M., Praneetha, S., Kashyap, P. \& Somasundaram, E. (2019). Genetic variability and character association studies in French bean (Phaseolus vulgaris) in Nilgiri hills of Tamil Nadu. Indian Journal of Agricultural Sciences, 89(12), 20092013.

https://www.researchgate.net/publication/3443

76537_Genetic_variability_and_charact er_association_studies_in_French_bean _Phaseolus_vulgaris_in_Nilgiri_hills_o f_Tamil_Nadu.

Nukasani, V., Nilkanth, R. P., Swati, B., Shradha, D. \& Sachin, M. S. (2013). Genetic variability, correlation and path analysis in wheat. Journal of Wheat Research, 5(2), 48-51. 2013.

https://sawbar.in/wpcontent/uploads/2018/07/Geneticvariability-correlation-and-pathanalysis-in-wheat-1.pdf.

Ojha, R., Sarkar, A., Aryal, A., Rahul, K. C., Tiwari, S., Poudel, M., Pant, K. R. \& Shrestha, J. (2018). Correlation and path coefficient analysis of wheat (Triticum aestivum L.) genotypes. Farming and Management, 3(2), 136-141. https://doi.org/10.31830/24568724.2018.0002.19.

Rachovska, G. \& Uhr, Zl. (2010). Inheritance of quantitative characteristics associated with productivity of $\mathrm{F} 1$ hybrids winter common wheat. Field Crops Studies, 6(3), 361-367.

http://fcs.dai-

gt.org/bg/index.php?page $=$ tom $\&$ idt $=10$ $\& i d b=14 \& i d a=97$.

Shah, S., Sharma, G. \& Sharma, N. (2010). Heritability, genetic variability correlation and non-hierarchial euclidean cluster analysis of different almond (Prunus dulcis) genotypes. Indian Journal of Agricultural Sciences, 80(7), 576-583.

Shahidullah, S., Marker, S. \& Bhattacharjee, I. (2017). Correlation and path coefficient analysis of some quantitative traits in bread wheat. Journal of Pharmacognosy and Phytochemistry, 6(4), 258-262.

https://www.phytojournal.com/archives/?year= $2017 \&$ vol $=6 \&$ issue $=4 \&$ Article $I d=1354$

Shara, J. H., Omer, B. \& Rshead, K. (2016). The simple correlation coefficient and path analysis of grain yield and its related components for some genotypes of wheat (Triticum aestivum L.) for two seasons in Iraqi Kurdistan. Journal of Medicinal Plants Studies, 4(1), 68-70.

https://www.plantsjournal.com/archives/?year= 2016\&vol=4\&issue $=1 \&$ part=B.

Shrief, S. A., El-Shafi, A. M. A., El-Ssadi, S. A. \& El-Lattif, A. H. M. (2019). Meanperformance, interrelationships and path analysis of yield traits in bread wheat (Triticum aestivum L.) crosses. Plant Archives, 19(2), 2425-2435.

http://www.plantarchives.org/19-2/24252435\%20(5305).pdf.

Sokoto, M. B., Abubakar, I. U. \& Dikko, A. U. 
(2012). Correlation analysis of some growth, yield, yield components and grain quality of wheat (Triticum aestivum L.). Nigerian Journal of Basic and Applied Science, 20(4), 349-356. http://www.ajol.info/index.php/njbas/in dex.

Soleymanfard, Y., Naseri, R. \& Moradi, M. (2012). The study of genetic variation and factor analysis for agronomic traits of durum wheat genotypes using cluster analysis and path analysis under stress condition in western Iran. International Research Journal of Applied and Basic Science, 3(3), 479-485. https://irjabs.com/files_site/paperlist/r_ 320_121110000932.pdf.

Stoyanov, X. (2013). Correlation between the spike characteristics in common winter wheat varieties (Triticum aestivum L.). Scientific works of the Institute of Agriculture - Karnobat, 2(1), 95-104.

https://core.ac.uk/download/pdf/35338722.pdf.

Stoyanov, G. \& Dunchev, D. (2020). Influence of the leaf fertilization on the productivity of two common wheat varieties. Agricultural University Plovdiv, Scientific Works, LXII (1):169175.

https://doi.org/10.22620/sciworks.2020.01.019. Stojsin, M M, Zecevic, V, Petrovic S, Dimitrijevic, M, Micanovic, D, Banjac, B \& Knezevic, D. (2018). Variability, correlation, path analysis and stepwise regression for yield components of different wheat genotypes. Genetika, 50(3), 817-828.

https://doi.org/10.2298/GENSR1803817M.

Tsenov, N., Kostov, K., Todorov, I., Panayotov, I., Stoeva, I., Atanassova, D., Mankovsky, I. \& Chamurliysky, P. (2009). Problems, achievements and prospects in breeding for grain productivity of winter wheat. Field Crops Studies, V-2:261-273. http://fcs.dai-

gt.org/bg/pdf/fulltext_V_2_7.pdf.

Verma, S. P., Pathak, V. N. \& Verma, O. P. (2019). Interrelationship between yield and its contributing traits in wheat (Triticum aestivum L). International Journal of Current Microbiology and Applied Sciences, 8(2), 3209-3215.

https://doi.org/10.20546/ijcmas.2019.802.375. 